Acupuncture is a complementary and alternative medical treatment (CAM) which is increasingly used in the care of cancer patients. Traditionally derived from Chinese medicine, nowadays it is becoming a part of evidence-based oncology. The use of acupuncture in these patients has been recommended by the American Cancer Society (ACS) for the treatment of side effects associated with conventional cancer therapy and cancer-related ailments. A growing body of evidence supports the use of acupuncture in the treatment of cancer-induced pain and chemotherapy-related nausea and vomiting. Also other indications, such as xerostomia, fatigue, hot flashes, anxiety and peripheral neuropathy, are being constantly evaluated. This article summarizes the most important discoveries related to the possible usefulness of this method in contemporary oncology. Emphasis is placed on the results of randomized controlled trials with an adequate level of evidence. However, explanation of the mechanisms responsible for these effects requires confirmation in further studies with an adequate level of evidence. In future, acupuncture may become an interesting and valuable addition to conventional medicine.

Key words: acupuncture, cancer, complementary and alternative treatment, side effects, supportive treatment.

Contemp Oncol (Pozn) 2016; 20 (2): 119-123 DOI: $10.5114 /$ wo.2016.60065

\section{Acupuncture: could it become everyday practice in oncology?}

\author{
Aneta Kilian-Kita, Mirosława Puskulluoglu, Kamil Konopka, \\ Krzysztof Krzemieniecki
}

Department of Clinical Oncology, University Hospital in Krakow, Krakow, Poland

\section{Introduction}

Complementary and alternative medical treatment (CAM) has gained significant interest in recent years [1]. Although the list of CAM has changed over the years, the Office of Alternative Medicine (established at the National Institutes of Health $[\mathrm{NIH}]$ in the USA) nowadays recognizes five major categories [2]. Acupuncture, belonging to the Manipulative Therapies category, due to its low cost, safety (considering all possible contraindications) and the minimal number of side effects is gaining popularity among patients [3]. Acupuncture has repeatedly been reported to be useful in oncological practice in alleviating side effects of anti-tumor treatment. Numerous clinical trials of acupuncture indicate its potential role in fighting the following ailments: nausea and chemotherapy-induced vomiting, pain, xerostomia, vasomotor symptoms, neutropenia, fatigue, anxiety, insomnia, lymphoedema after mastectomy, and peripheral neuropathy [4-16]. A sudden increase in the number of studies on acupuncture in oncology was first noted in 1997, when at the NIH conference a consensus was reached on the use of acupuncture, which was then acknowledged as a useful medical procedure [17]. This article reviews the literature concerning the referred studies.

\section{What is acupuncture?}

Acupuncture is a method of treatment that has its origins in Traditional Chinese Medicine and is based on over 4,000 years of empirical evidence. The technique involves the insertion of thin needles into specific locations (energy points) on the patient's body along energy pathways or meridians. According to Chinese philosophy, the hypothetical substance Qi (vital energy) flows in the human body along the meridians, and blockage of Qi leads to a particular ailment [18]. There are 12 main and 8 extra meridians. All the main meridians consist of internal channels connected with the 12 body organs and the external channels spreading symmetrically on the skin surface. The literature describes around 360 energy points located on the external parts of the meridians. Acupuncture is considered to cure diseases by stimulating particular acupoints and removing blockage of Qi [19]. Figures 1-3 present acupuncture meridian pathways.

Although acupuncture has been studied extensively in both animal and human models, little is known about its mechanisms that could explain acupuncture's therapeutic qualities. Table 1 shows suggested mechanisms of acupuncture. This treatment method has been the focus of increased interest, which has resulted in a growing number of studies.

\section{Acupuncture as supportive treatment}

Chemotherapy agents are considered to be medications with the most severe side effects, which in many cases may force the patient to abandon therapy. Because of that, proper alleviation of side effects is most crucial. Acupuncture should not be seen as a replacement for modern medicines, but rather an adjunct with a low level of procedure-related complications 
that may enhance efficacy and in some cases allow the dosage of other drugs to be reduced. Acupuncture as part of supportive treatment in oncology has been tested for numerous indications. The strongest evidence from a ran-

Table 1. Possible mechanisms of action of acupuncture domized controlled trial (RCT) with low risk of bias supports the use of acupuncture for control of nausea and vomiting related to chemotherapy [25]. This indication seems to be very important, as the high emetogenicity

\begin{tabular}{|c|c|c|}
\hline Possible mechanisms of action of acupuncture & Effects & References \\
\hline $\begin{array}{l}\text { Local inflammatory response } \\
\text { - histamine } \\
\text { - prostaglandins } \\
\text { - chemokines }\end{array}$ & $\begin{array}{l}\text { - increasing permeability and dilatation of the } \\
\text { capillaries } \\
\text { - promotion of blood flow to the site } \\
\text { - initiation of the migration of phagocytes and } \\
\text { signaling them to increase production of various } \\
\text { mediators }\end{array}$ & {$[20]$} \\
\hline $\begin{array}{l}\text { Cytokines } \\
\text { - decreased expression of IL-6, } \beta \text { NGF and TIMP-1 } \\
\text { - reducing proinflammatory cytokines IL-1, IL-6, TNF- } \alpha \text { through } \\
\text { activation of CB2 receptors }\end{array}$ & $\begin{array}{l}\text { - anti-inflammatory effect } \\
\text { - antinociceptive effect on inflammatory pain }\end{array}$ & {$[21,22]$} \\
\hline $\begin{array}{l}\text { ANS } \\
\text { - increasing synchronization between the two branches of the ANS } \\
\text { and improvement of HRV }\end{array}$ & - mediating global physiological regulation & [23] \\
\hline $\begin{array}{l}\text { Stem cells } \\
\text { - increasing levels of non-differentiated progenitor of stem cells } \\
\text { CD133+ and CD34- cell in the serum of patients after spinal cord } \\
\text { injury } \\
\text { - promotion of proliferation and differentiation of neural stem cells, } \\
\text { up-regulation of the growth factors and the expression of VEGF } \\
\text { mRNA in the rats ischemic brain }\end{array}$ & $\begin{array}{l}\text { - spinal cord stem cell mobilization } \\
\text { - protection cerebral injuries after ischemia and } \\
\text { promotion nerve regeneration }\end{array}$ & [24] \\
\hline
\end{tabular}

Table 2. Possible mechanisms of action of acupuncture and its effectiveness in the treatment of various types of ailments related to cancer therapy

\begin{tabular}{|c|c|c|c|}
\hline Condition & Possible molecular mechanisms of action & Clinical trials & References \\
\hline \multicolumn{4}{|c|}{ Randomized control trials } \\
\hline $\begin{array}{l}\text { Nausea and } \\
\text { chemotherapy- } \\
\text { induced } \\
\text { vomiting }\end{array}$ & $\begin{array}{l}\text { Multiple mechanisms } \\
\text { - influences the endogenous opioid system } \\
\text { and changes the serotonin transmission } \\
\text { - has effects on the gastric myoelectrical } \\
\text { activity } \\
\text { - increases vagal modulation } \\
\text { - influences the cerebellar vestibular activities }\end{array}$ & $\begin{array}{l}\text { RCT: } \\
\text { - acupuncture significantly reduced the number } \\
\text { of episodes of emesis between three groups: } \\
\text { electroacupuncture, minimal needling and } \\
\text { pharmacotherapy alone (median number of episodes, } \\
5,10 \text {, and 15, respectively; } p<0.001 \text { ) }\end{array}$ & {$[26]$} \\
\hline Cancer pain & $\begin{array}{l}\text { Opioid peptides } \\
\text { - increased concentration level observed in the } \\
\text { serum and brain tissue after acupuncture } \\
\text { Neuromodulation } \\
\text { - activity modulation of the human brain areas } \\
\text { (activated in acute or chronic pain) during } \\
\text { acupuncture in neuroimaging (fMRI, PET, } \\
\text { EEG) }\end{array}$ & $\begin{array}{l}\text { Meta-analysis of RCTs: } \\
\text { - acupuncture did not make a better effect than drug } \\
\text { therapy ( } n=886 \text {; RR 1.12; } 95 \% \mathrm{Cl}: 0.98 \text { to } 1.28 ; p=0.09) \\
\text { - combination therapy (acupuncture with drug therapy) } \\
\text { was more effective than drug therapy alone ( } n=437 \text {; } \\
\text { RR } 1.36 ; 95 \% \mathrm{Cl}: 1.13-1.64 ; p=0.003 \text { ) }\end{array}$ & {$[7,8,27-31]$} \\
\hline $\begin{array}{l}\text { Chemotherapy- } \\
\text { induced } \\
\text { leucopoenia }\end{array}$ & $\begin{array}{l}\text { Multiple mechanisms } \\
\text { - promotes the release of WBC from bone } \\
\text { marrow } \\
\text { - prolonging the life of WBC } \\
\text { - increases the activity of CSFs } \\
\text { - promotes the proliferation of haemopoietic } \\
\text { stem cells } \\
\text { - reduces haemopoietic stem cells damage by } \\
\text { chemotherapy } \\
\text { - improves microcirculation }\end{array}$ & $\begin{array}{l}\text { Meta-analysis of RCTs from China: } \\
\text { - acupuncture was effective in increasing WBC level } \\
\text { - mean difference in the WBC level was } 1221 \mathrm{WBC} / \mu \mathrm{l} \\
(95 \% \mathrm{Cl}: 636-1807, p<0.0001) \\
\text { Pilot study from USA: } \\
\text { Significant increase in the median leukocyte value for } \\
\text { baseline value after acupuncture }(p=0.046) \text { : } \\
\text { - } 8600 \mathrm{WBC} / \mu \mathrm{l}, 95 \% \mathrm{Cl}: 4800-12000 \text { in the test group } \\
\text { - } 4400 \mathrm{WBC} / \mu \mathrm{l}, 95 \% \mathrm{Cl}: 2300-10000 \text { in the control group } \\
\text { Decrease in the frequency of occurrence of severe } \\
\text { leucopoenia ( } p=0.02) \text { : } \\
\text { - } 30 \% \text { in the test group } \\
\text { - } 90 \% \text { in the control group }\end{array}$ & {$[11,32-34]$} \\
\hline
\end{tabular}


Table 2. Cont.

\begin{tabular}{|c|c|c|c|}
\hline $\begin{array}{l}\text { Al-induced } \\
\text { arthralgias }\end{array}$ & $\begin{array}{l}\text { Multiple mechanisms } \\
\text { - increases the opioid peptides level } \\
\text { - improves blood flow }\end{array}$ & $\begin{array}{l}\text { RCT: } \\
\text { Significant difference between the test group and the } \\
\text { control group at } 6 \text { weeks of treatment was observed in: } \\
\text { - the mean BPI-SF worst pain scores (on the scale from } \\
0-10,10 \text { being the most intense pain; } 3.0 \text { vs. } 5.5 ; \\
p<0.001 \text { ) } \\
\text { - pain severity ( } 2.6 \text { vs. } 4.5 ; p=0.003 \text { ) } \\
\text { - pain-related interference ( } 2.5 \text { vs. } 4.5 ; p=0.002 \text { ) }\end{array}$ & [35] \\
\hline $\begin{array}{l}\text { Radiation- } \\
\text { induced } \\
\text { xerostomia }\end{array}$ & $\begin{array}{l}\text { Neural transmission: } \\
\text { - bilateral activation of the brain function } \\
\text { area in fMRI that is responsible for salivary } \\
\text { production } \\
\text { CGRP: } \\
\text { - increase the release of CGRP, which positively } \\
\text { affects the salivary flow rates }\end{array}$ & $\begin{array}{l}\text { RCT: } \\
\text { In the acupuncture group as compared to the control } \\
\text { group was observed: } \\
\text { - significant reduction in dry mouth symptoms measured } \\
\text { by means of the VAS }(p<0.05) \\
\text { - increase in unstimulated and stimulated salivary flow } \\
\text { and production }(p<0.001)\end{array}$ & {$[9,36,37]$} \\
\hline Hot flushes & $\begin{array}{l}\text { Neuromodulation } \\
\text { - increases endorphin release and decrease } \\
\text { noradrenalin and serotonin activity } \\
\text { in the central nervous system (make } \\
\text { thermoregulation more stable) } \\
\text { CGRP } \\
\text { - direct effect on the release of vasodilator - } \\
\text { CGRP in peripheral nerve endings }\end{array}$ & $\begin{array}{l}\text { RCT: } \\
\text { Significant reduction of hot flushes and sleep } \\
\text { disturbances was observed in: } \\
\text { - } 16 \text { patients ( } 52 \%) \text { of the test group } \\
\text { - } 7 \text { patients (24\%) of the control group. } \\
\text { - effect was obtained after the second acupuncture } \\
\text { session and lasted for the next } 12 \text { weeks after treatment }\end{array}$ & {$[38,39]$} \\
\hline $\begin{array}{l}\text { Anxiety-like } \\
\text { behaviour and } \\
\text { stress }\end{array}$ & $\begin{array}{l}\text { NPY and CRF } \\
\text { - increases NPY mRNA levels and reduces CRF } \\
\text { mRNA levels in the amygdala of rats after } \\
\text { acupuncture }\end{array}$ & $\begin{array}{l}\text { Randomized controlled experimental study: } \\
\text { - after } 10 \text { acupuncture sessions patients with generalized } \\
\text { anxiety disorders demonstrated significantly reduced } \\
\text { anxiety (85.7\%) following compared to a placebo group }\end{array}$ & {$[13,40,41]$} \\
\hline \multicolumn{4}{|c|}{ Non RCT studies } \\
\hline $\begin{array}{l}\text { Chemotherapy- } \\
\text { induced } \\
\text { peripheral } \\
\text { neuropathy }\end{array}$ & $\begin{array}{l}\text { Purinergetic signaling } \\
\text { - stimulating purinergic signals (increase } \\
\text { in the release of adenine nucleotides and } \\
\text { adenosine from skin keratinocytes) and } \\
\text { neurotransmission in the central and } \\
\text { peripheral nervous system }\end{array}$ & $\begin{array}{l}\text { Pilot study: } \\
\text { - acupuncture treatment for } 6 \text { weeks was effective in } 82 \% \\
(n=14) \text { of patients }\end{array}$ & [16] \\
\hline $\begin{array}{l}\text { Cancer-related } \\
\text { fatigue }\end{array}$ & - multicomponent & $\begin{array}{l}\text { Prospective, clinical study: } \\
\text { - significant improvement after } 2 \text { weeks of treatment was } \\
\text { observed with regard to: general fatigue }(p<0.001) \text {, } \\
\text { physical fatigue }(p=0.016) \text {, activity }(p=0.004) \text { and } \\
\text { motivation ( } p=0.024) \text {, and lasted for } 2 \text { weeks after the } \\
\text { end of the intervention }\end{array}$ & [12] \\
\hline $\begin{array}{l}\text { CRT-induced } \\
\text { dysphagia }\end{array}$ & $\begin{array}{l}\text { Multiple mechanisms } \\
\text { - increase the saliva production } \\
\text { - restore swallowing reflex } \\
\text { - inhibition the fibrosis process }\end{array}$ & $\begin{array}{l}\text { Case series study: } \\
\text { - The treatment was effective in: } \\
9 / 10 \text { patients ( } 90 \%) \text { of the test group (subjective } \\
\text { improvement in the swallowing function, decrease in } \\
\text { dry mouth symptoms, pain and fatigue level) } \\
\text { - in } 6 / 7 \text { patients ( } 86 \% \text { it was possible to remove the } \\
\text { PEG tube (a median time of } 114 \text { days from the last CRT } \\
\text { session and acupuncture treatment, the range from } \\
49 \text { to } 368 \text { days) }\end{array}$ & [42] \\
\hline Hiccup & $\begin{array}{l}\text { Modulation of the hiccup reflex arc } \\
\text { - locally: changing blood perfusion, activating } \\
\text { the autonomic nervous system, regulating } \\
\text { inflammatory mediators } \\
\text { - centrally: influences the hiccup center by } \\
\text { modulating the secretion of neurotransmitters } \\
\text { and neurohormones (endogenous opioids, } \\
\text { norepinephrine, serotonin, substance P) }\end{array}$ & $\begin{array}{l}\text { Case series study: } \\
\text { After } 1-3 \text { courses of treatment (over a } 1-7 \text {-day period) was } \\
\text { observed: } \\
\text { - complete symptom relief in } 13 \text { patients ( } 81 \% \text {, } \\
\quad p<0.0001) \text {; } \\
\text { - partial symptom relief in } 3 \text { patients }(18.8 \%) \\
\text { - substantial improvement in discomfort }(p<0.0001) \text {, } \\
\text { fatigue }(p=0.0078) \text { and anxiety }(p<0.0001)\end{array}$ & [43] \\
\hline Lymphoedema & - unclear & $\begin{array}{l}\text { Pilot study: } \\
\text { After } 4 \text { weeks of treatment, } 30 \% \text { reduction of oedema in } \\
\text { comparison to the baseline results was observed in } 4 / 9 \\
\text { patients }(44.5 \%)\end{array}$ & [15] \\
\hline
\end{tabular}




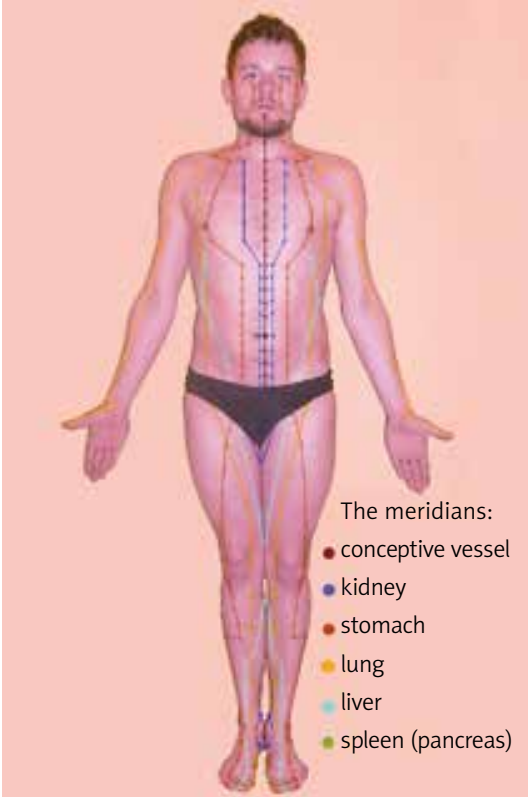

Fig. 1. The course of main meridians on the anterior surface of the body

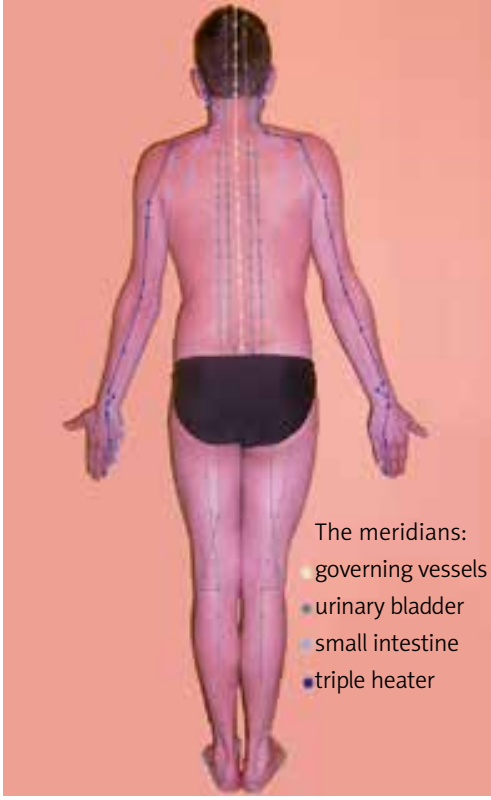

Fig. 2. The course of main meridians on the posterior surface of the body

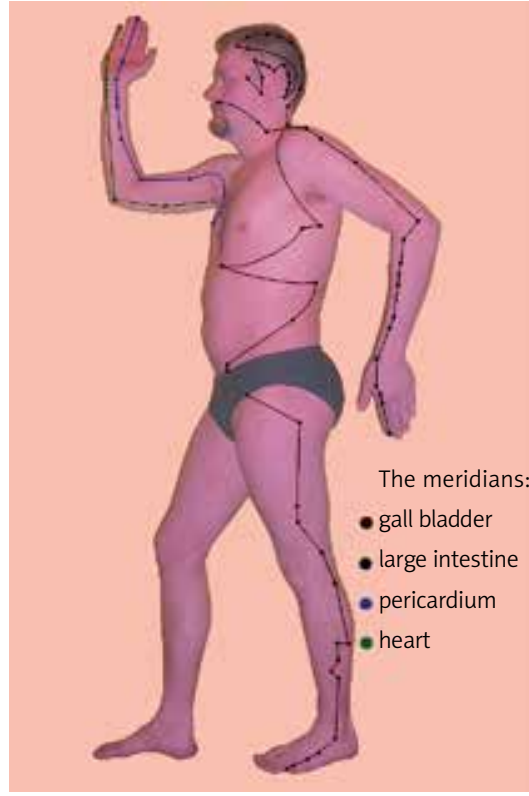

Fig. 3. The course of main meridians on the lateral surface of the body of many cytostatic agents is hard to control even with three-drug therapy [26]. Despite many RCTs on treatment of other chemotherapy-induced side effects, the level of evidence is not yet satisfactory, but considering its relative safety, acupuncture may be useful in everyday practice. Descriptions of these clinical trials on the effectiveness of acupuncture in minimizing cancer treatment-related side effects are summarized in Table 2 .

\section{Level of evidence issue}

A recently published systemic review stated that other indications, such as pain, xerostomia, vasomotor symptoms, fatigue, mood disorders, and insomnia, were not evaluated in RCTs with an appropriate level of evidence [44]. One of the major problems with the reviewed studies is their poor methodological quality, mostly difficulty with blinding and a low number of subjects. Also the optimal design of such studies (acupuncture vs placebo, acupuncture vs sham acupuncture) has not been established yet [45]. In spite of satisfactory results in most of these studies, further research on a larger group of patients is necessary.

\section{Summary}

In an oncological setting, acupuncture is still being constantly reviewed. Nevertheless, the present available evidence suggests that acupuncture may become a safe, low-cost and efficient form of complementary therapy in modern oncology. The potential role of acupuncture has been found in alleviation of various symptoms, but the data from the majority of clinical studies on acupuncture are heterogeneous. The incomplete description of procedural methodology and insufficient patient groups limit their value. Thus, further research on a larger scale on the potential use of acupuncture in contemporary oncology is required. It should be emphasized that alternative medicine may become the source of a number of interesting concepts worth examining and testing in research and clinical settings.

\section{Acknowledgments}

The authors would like to thank Ms Joanna Gołąb for editing the article.

The authors declare no conflict of interest.

\section{References}

1. Molassiotis A, Fernadez-Ortega P, Pud D, et al. Use of complementary and alternative medicine in cancer patients: a European survey. Ann. Oncol 2005; 16: 655-63.

2. Hök J, Tishelman C, Ploner A, et al. Mapping patterns of complementary and alternative medicine use in cancer: an explorative cross-sectional study of individuals with reported positive "exceptional" experiences. BMC Complement Altern Med 2008; 8: 48.

3. White A. A cumulative review of the range and incidence of significant adverse events associated with acupuncture. Acupunct Med 2004; 22: 122-33.

4. Streitberger K, Ezzo J, Schneider A. Acupuncture for nausea and vomiting: an update of clinical and experimental studies. Auton Neurosci 2006; 129: 107-17.

5. Yang Y, Zhang Y, Jing N, et al. Electroacupuncture at Zusanli (ST 36) for treatment of nausea and vomiting caused by the chemotherapy of the malignant tumor: a multicentral randomized controlled trial. Zhongguo Zhen Jiu 2009; 29: 955-8.

6. Gottschling S, Reindl TK, Meyer S, et al. Acupuncture to alleviate chemotherapy-induced nausea and vomiting in pediatric oncology - a randomized multicenter crossover pilot trial. Klin Padiatr 2008; 220: 365-70.

7. Dang W, Yang J. Clinical study on acupuncture treatment of stomach carcinoma pain. J Tradit Chin Med 1998; 18: 31-8. 
8. Alimi D, Rubino C, Pichard-Léandri E, et al. Analgesic effect of au ricular acupuncture for cancer pain: a randomized, blinded, controlled trial. J Clin Oncol 2003; 21: 4120-6.

9. Braga FP, Lemos Junior CA, Alves FA, Migliari DA. Acupuncture for the prevention of radiation-induced xerostomia in patients with head and neck cancer. Braz Oral Res 2011; 25: 180-5.

10. Liljegren A, Gunnarsson P, Landgren B-M, et al. Reducing vasomotor symptoms with acupuncture in breast cancer patients treated with adjuvant tamoxifen: a randomized controlled trial. Breast Cancer Res. Treat. 2012; 135: 791-8.

11. Lu W, Matulonis UA, Doherty-Gilman A, et al. Acupuncture for chemotherapy-induced neutropenia in patients with gynecologic malignancies: a pilot randomized, sham-controlled clinical trial. J Altern Complement Med 2009; 15: 745-53.

12. Molassiotis A, Sylt P, Diggins H. The management of cancer-related fatigue after chemotherapy with acupuncture and acupressure: a randomised controlled trial. Complement Ther Med 2007; 15: 228-37.

13. Eich $\mathrm{H}$, Agelink MW, Lehmann E, et al. Acupuncture in patients with minor depressive episodes and generalized anxiety. Results of an experimental study. Fortschr Neurol Psychiatr 2000; 68: 137-44.

14. Frisk J, Källström A-C, Wall N, et al. Acupuncture improves health-related quality-of-life (HRQoL) and sleep in women with breast cancer and hot flushes. Support Care Cancer 2012; 20: 715-24.

15. Cassileth BR, Van Zee KJ, Chan Y, et al. A safety and efficacy pilot study of acupuncture for the treatment of chronic lymphoedema. Acupunct Med 2011; 29: 170-2.

16. Donald GK, Tobin I, Stringer J. Evaluation of acupuncture in the management of chemotherapy-induced peripheral neuropathy. Acupunct Med 2011; 29: 230-3.

17. NIH. Consensus Conference. Acupuncture. JAMA 1998; 280: 1518 24.

18. Zhao XL, Han JX. The connotation of the Quantum Traditional Chi nese Medicine and the exploration of its experimental technology system for diagnosis. Drug Discov Ther 2013; 7: 225-32.

19. Perlow BW. Acupuncture: its theory and use in general practice. Proc R Soc Med 1973; 66: 426-8.

20. Chae Y, Hong M-S, Kim G-H, et al. Protein array analysis of cyto kine levels on the action of acupuncture in carrageenan-induced inflammation. Neurol Res 2007; 29: S55-8.

21. Su T-F, Zhao Y-Q, Zhang L-H, et al. Electroacupuncture reduces the expression of proinflammatory cytokines in inflamed skin tissues through activation of cannabinoid CB2 receptors. Eur J Pain 2012 16: 624-35.

22. Anderson B, Nielsen A, McKee D, et al. Acupuncture and heart rate variability: a systems level approach to understanding mechanism. Explore (NY) 2012; 8: 99-106.

23. Moldenhauer S, Burgauner M, Hellweg R, et al. Mobilization of CD133(+)CD34(-) cells in healthy individuals following whole-body acupuncture for spinal cord injuries. J Neurosci Res 2010; 88: 1645 50

24. Yang Z, Chen P, Yu H, et al. Research advances in treatment of cerebral ischemic injury by acupuncture of conception and governor vessels to promote nerve regeneration. Zhong Xi Yi Jie He Xue Bao 2012; 10: 19-24.

25. Shen J, Wenger N, Glaspy J, et al. Electroacupuncture for control of myeloablative chemotherapy-induced emesis: A randomized controlled trial. JAMA 2000; 284: 2755-61.

26. Gralla RJ, de Wit R, Herrstedt J, et al. Antiemetic efficacy of the neurokinin-1 antagonist, aprepitant, plus a 5HT3 antagonist and a corticosteroid in patients receiving anthracyclines or cyclophos phamide in addition to high-dose cisplatin: analysis of combined data from two Phase III randomized clinical trials. Cancer 2005; 104: 864-8.

27. Han J-S. Acupuncture and endorphins. Neurosci Lett 2004; 361 258-61.

28. Han JS, Xie GX, Zhou ZF, et al. Acupuncture mechanisms in rabbits studied with microinjection of antibodies against beta-endorphin enkephalin and substance P. Neuropharmacology 1984; 23: 1-5.

29. Wu GC, Zhu J, Cao X. Involvement of opioid peptides of the preoptic area during electroacupuncture analgesia. Acupunct Electroth er Res 1995; 20: 1-6.
30. Hsieh JC, Tu CH, Chen FP, et al. Activation of the hypothalamus characterizes the acupuncture stimulation at the analgesic point in human: a positron emission tomography study. Neurosci Lett 2001; 307: 105-8.

31. Choi TY, Lee MS, Kim TH, et al. Acupuncture for the treatment of cancer pain: a systematic review of randomised clinical trials. Support Care Cancer 2012; 20: 1147-58

32. Zhao X, Wang H, Tian K, et al. Review on mechanisms of acupuncture-moxibustion against leukopenia due to chemotherapy induced myeloid inhibition. Acupuncture Research 2003; 1: 70-3.

33. Zhao X, Huang X, Wang H, et al. Study on the Mechanism of Acupuncture in Fighting Chemotherapeutic Marrow Depression and Enhancing WBC. Shanghai Journal of Acupuncture and Moxibustion 2003; 1: 29-33.

34. Lu W, Hu D, Dean-Clower E, et al. Acupuncture for chemotherapy-induced leukopenia: exploratory meta-analysis of randomized controlled trials. J Soc Integr Oncol 2007; 5: 1-10.

35. Crew KD, Capodice JL, Greenlee H, et al. Randomized, blinded, sham-controlled trial of acupuncture for the management of aromatase inhibitor-associated joint symptoms in women with early-stage breast cancer. J Clin Oncol 2010; 28: 1154-60.

36. Deng G, Hou BL, Holodny AI, Cassileth BR. Functional magnetic resonance imaging (FMRI) changes and saliva production associated with acupuncture at LI-2 acupuncture point: a randomized controlled study. BMC Complement Altern Med 2008; 8: 37.

37. Dawidson I, Angmar-Mânsson B, Blom M, et al. Sensory stimulation (acupuncture) increases the release of calcitonin gene-related peptide in the saliva of xerostomia sufferers. Neuropeptides 1999; 33: 244-50.

38. Spetz Holm A-CE, Frisk J, Hammar ML. Acupuncture as treatment of hot flashes and the possible role of calcitonin gene-related Peptide. Evid Based Complement Alternat Med 2012; 2012: 579321.

39. Bokmand S, Flyger H. Acupuncture relieves menopausal discomfort in breast cancer patients: a prospective, double blinded, randomized study. Breast 2013; 22: 320-3.

40. Park HJ, Chae Y, Jang J, et al. The effect of acupuncture on anxiety and neuropeptide $Y$ expression in the basolateral amygdala of maternally separated rats. Neurosci Lett 2005; 377: 179-84

41. Chae Y, Yeom M, Han JH, et al. Effect of acupuncture on anxiety-like behavior during nicotine withdrawal and relevant mechanisms. Neurosci Lett 2008; 430: 98-102.

42. Lu W, Posner MR, Wayne P, et al. Acupuncture for dysphagia after chemoradiation therapy in head and neck cancer: a case series report. Integr Cancer Ther 2010; 9: 284-90.

43. Ge AX, Ryan ME, Giaccone G, et al. Acupuncture treatment for persistent hiccups in patients with cancer. J Altern Complement Med 2010; 16: 811-6.

44. Garcia MK, McQuade J, Haddad R, et al. Systematic review of acupuncture in cancer care: a synthesis of the evidence. J Clin Oncol 2013; 31: 952-60

45. White AR, Filshie J, Cummings TM; International Acupuncture Research Forum. Clinical trials of acupuncture: consensus recommendations for optimal treatment, sham controls and blinding. Complement Ther Med 2001; 9: 237-45.

\section{Address for correspondence}

\section{Mirosława Puskulluoglu}

Department of Clinical Oncology

University Hospital in Krakow

Śniadeckich 10

31-501 Krakow, Poland

e-mail: mircoll@wp.p

Submitted: 16.03 .2014

Accepted: 16.07 .2014 